\title{
GRAZING EFFECTS ON PRECIPITATION-DRIVEN ASSOCIATIONS BETWEEN SAGEBRUSH AND PERENNIAL GRASSES
}

\author{
Maike F. Holthuijzen ${ }^{1}$ and Kari E. Veblen ${ }^{1,2}$
}

\begin{abstract}
Aвstract.-While many studies have addressed the effect of individual stresses on plant-plant associations, few have addressed the effects of co-occurring stresses. We therefore investigated how associations between Wyoming big sagebrush (Artemisia tridentata ssp. wyomingensis) and 2 native grasses (Poa secunda and Elymus elymoides) responded to different combinations of grazing and moisture stresses in the Great Basin, USA. Positive (i.e., facilitative) interactions between nurse plants and their beneficiaries are predicted to increase with increasing moisture limitation and grazing stress, but these interactions may break down at extreme levels of stress. We hypothesized that (1) competitive interactions and negative shrub-grass spatial associations would occur under the least stressful conditions (low grazing intensity/high precipitation); (2) positive shrub-grass spatial associations would dominate at intermediate levels of stress (high grazing intensity/high precipitation and low grazing intensity/low precipitation); and (3) negative grass-shrub relationships would dominate at extreme levels of stress (high grazing/low precipitation). We sampled 5 site pairs (high vs. low grazing intensity) that occurred over a precipitation gradient. We assessed how abundance of the 2 grasses $P$. secunda and E. elymoides responded to sagebrush microsite (canopy vs. interspace), grazing intensity, and precipitation. We found that both grass species were positively associated with A. tridentata canopy microsites at low annual precipitation levels. However, grazing stress appeared to weaken this effect for $P$. secunda, indicating, as we predicted, a potential breakdown of facilitative interactions in highly stressful conditions. Although we predicted that facilitation would dominate in moderately stressful conditions, we only found this to be true (for both grasses) in one of the 2 moderately stressful scenarios (low grazing/low precipitation). Our results provide insights into how Great Basin plant communities may respond to the separate and combined effects of grazing and drought stresses, both of which may intensify in the future.
\end{abstract}

RESUMEN.-Aunque muchos estudios han explorado el efecto del estrés individual en las asociaciones planta-planta, pocos se han enfocado en los efectos del estrés co-ocurrente. Por ello, estudiamos el modo en el que se relacionan la gran artemisa de Wyoming (Artemisia tridentata ssp. wyomingensis) y dos pastos nativos (Poa secunda y Elymus elymoides) y cómo responden a dos combinaciones diferentes de pastoreo y al estrés hídrico en la Gran Cuenca (Great Basin), Estados Unidos. Predecimos que las interacciones positivas (por ejemplo, la facilitación) entre las plantas nodrizas y sus beneficiarias aumenten con el incremento de los límites de humedad y de estrés producido por el pastoreo, pero podrían desajustarse en rangos de estrés extremo. Planteamos varias hipótesis: (1) las interacciones de competencia y las asociaciones espaciales negativas entre artemisas y pastos ocurrirían bajo las condiciones menos estresantes (baja intensidad de pastoreo - alta precipitación); (2) las asociaciones espaciales positivas entre artemisas y pastos dominarían a niveles intermedios de estrés (alta intensidad de pastoreo - alta precipitación y baja intensidad de pastoreo - baja precipitación); y (3) a niveles extremos de estrés (pastoreo alto - baja precipitación), dominarían las relaciones negativas pasto-artemisa. Tomamos muestras de cinco pares por sitio (alta vs baja intensidad de pastoreo) producidos durante un gradiente de precipitación. Evaluamos cómo la abundancia de los dos pastos (P. secunda y E. elymoides) respondía al micro-hábitat de las artemisas (follaje vs. inter-espacios), a la intensidad de pastoreo y a la precipitación. Encontramos que ambas especies de pastos se asociaron positivamente como los micro-hábitats de follaje de A. tridentata en bajos niveles de precipitación anuales. Sin embargo, el estrés por pastoreo pareció debilitar este efecto en una de las especies de pasto $P$. secunda, lo que indica, tal y como se había previsto, una ruptura potencial de la facilitación en condiciones muy estresantes. A pesar de que predijimos que la facilitación dominaría en condiciones moderadamente estresantes, sólo encontramos esto (en ambos pastos) en uno de los dos escenarios moderadamente estresantes (bajo pastoreo - baja precipitación). Nuestros resultados proporcionan una visión de cómo las comunidades vegetales de la Gran Cuenca pueden responder a los efectos individuales y combinados de las tensiones de pastoreo y la sequía, los cuales podrían intensificarse en el futuro.

Positive plant-plant interactions have been documented across ecosystems worldwide (Brooker et al. 2008), including many rangeland systems (He et al. 2013). According to the stress gradient hypothesis (Bertness and Callaway 1994), the frequency and importance of positive (i.e., facilitative) plant-plant interactions are predicted to increase with increasing

\footnotetext{
${ }^{1}$ Department of Wildland Resources and Ecology Center, Utah State University, Logan, UT, 84322-5230.
}

${ }^{2}$ Corresponding author. E-mail: kari.veblen@usu.edu 
abiotic or biotic environmental stress. These facilitative effects can break down, however, under extreme levels of either abiotic (Maestre et al. 2005) or biotic (Smit et al. 2009, Saiz and Alados 2012) stress. Both cases result in a hump-shaped pattern wherein facilitative plant-plant interactions peak at intermediate stress levels (Smit et al. 2009, He and Bertness 2014). Less clear and rarely studied, however, is how these patterns respond to co-occurring abiotic and biotic stresses.

Positive plant-plant interactions become more frequent or intense with increasing moisture stress, a common and pervasive type of abiotic stress (Holmgren et al. 1997, Reisner 2010, Ziffer-Berger et al. 2014; but see Maestre et al. 2005). Under high moisture stress, a "nurse" plant may benefit a neighboring beneficiary plant by improving soil moisture conditions (Chambers 2001, Maestre et al. 2001), mediating soil temperatures and reducing evapotranspiration (Moro et al. 1997, Ramírez et al. 2015), enhancing soil nutrient availability (Liu et al. 2013) and organic matter (Ramírez et al. 2015), or decreasing solar radiation (Valiente-Banuet and Ezcurra 1991, Maestre et al. 2001). At very high levels of abiotic stress (e.g., extreme drought), however, facilitative effects of neighbors on beneficiaries can be outweighed by competition for severely limited resources (Tielbörger and Kadmon 2000).

Biotic stress, such as ungulate grazing, also affects the strength of nurse-beneficiary relationships (Smit et al. 2009). Generally, positive plant-plant interactions increase in response to increases in grazing stress (Graff and Aguiar 2011, Anthelme et al. 2014), mainly due to the physical protection of vulnerable palatable species by less-palatable or thorny neighbors (Atsatt and O'Dowd 1976, Rebollo et al. 2002, Callaway et al. 2005, Pazos et al. 2007). However, facilitation may break down at the highest levels of biotic stress (Smit et al. 2009, Saiz and Alados 2012). For example, under heavy grazing pressure, ungulate grazers are less selective and may browse less-preferred (e.g., thorny or otherwise low-palatability) nurse plant species, which may in turn damage nurse plants and reduce their effectiveness at protecting palatable species growing under their canopies (Smit et al. 2007). At higher grazing pressure, grazers may also search more intensely for food resources (Soliveres et al. 2011).
How nurse-beneficiary relationships respond to the interaction of environmental stresses such as herbivory and moisture stress is poorly understood (Verwijmeren et al. 2014). A few studies suggest that co-occurrence of herbivory and moisture stresses increases positive plant interactions (but see Howard et al. 2012, Anthelme et al. 2014). Perea and Gil (2014) observed that concomitant decreases in moisture levels and increases in ungulate herbivory increased facilitative effects between shrubs and tree seedlings in a Mediterranean ecosystem, and Veblen (2008) reported that grazing-mediated facilitation between 2 grasses only occurred during the most abiotically stressful (dry) times. In contrast, Verwijmeren et al. (2014) and Noumi et al. (2015) reported only a slight degree of grazingmediated facilitation when abiotic conditions were less stressful (i.e., under higher moisture). Under dual (biotic and abiotic) stresses, facilitation may be more likely to break down (Le Bagousse-Pinguet et al. 2012). For example, in abiotically stressful environments where forage availability is limited, grazing ungulates may search more intensely for palatable plants growing under nurse plant canopies (Soliveres et al. 2011). Better understanding of the separate and combined influence of biotic vs. abiotic stresses on nurse plant relationships will provide important insights into what drives plant distributions, particularly in arid and semiarid ecosystems where moisture and herbivory stresses are common (Puigdefábregas 1998).

An ideal place to address questions about the relative roles of biotic and abiotic stresses in nurse plant relationships is the Great Basin, USA. In areas of the Great Basin dominated by sagebrush (Artemisia tridentata), annual precipitation can be as low as $177 \mathrm{~mm}$ (7 inches; Daly and Bryant 2013), and the vast expanse of land is heavily utilized for livestock grazing (Davies et al. 2011). Previously, it has been shown that native perennial grasses form positive spatial patterns with $A$. tridentata under more abiotically stressful environmental conditions (Davies et al. 2007, Holthuijzen and Veblen 2015, Reisner et al. 2015). Artemisia tridentata can facilitate neighboring species via amelioration of harsh conditions in its subcanopy and thus reduce evapotranspiration (Callaway et al. 1996), mediate soil temperatures (Davies et al. 2007), increase soil 


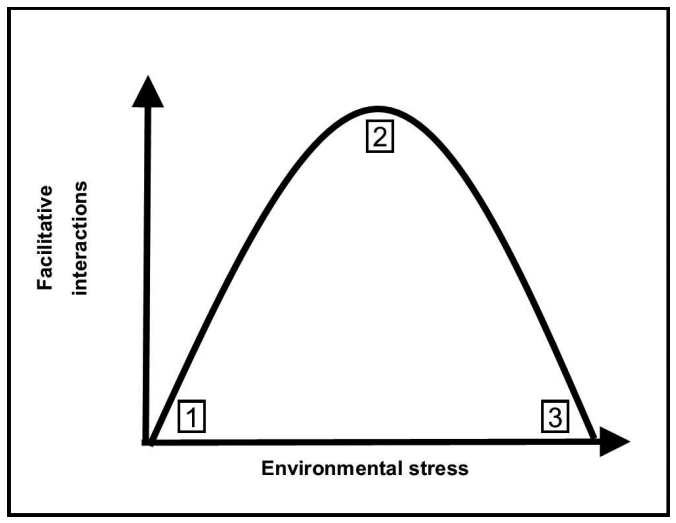

Fig. 1. Hypothesized relationship between a gradient of environmental stress ( $x$ axis) and the frequency or intensity of facilitative interactions ( $y$ axis). Here, both grazing and (lack of) precipitation contribute to environmental stress: $1=$ "low stress" (low grazing intensity/high precipitation), $2=$ "intermediate stress" (high grazing intensity/high precipitation or low grazing intensity/low precipitation), 3 = "extreme stress" (high grazing/low precipitation).

water via hydraulic lift (Richards and Caldwell 1987), and concentrate soil nutrients (Cardon et al. 2013). Because A. tridentata has relatively low palatability to domestic cattle (Howard 1999) and its canopy provides a physical barrier to grazing cattle, A. tridentata may also facilitate perennial grasses by providing them with a grazing refuge. However, only one study, in the southeastern Oregon portion of the Great Basin, has explicitly considered both moisture and grazing stress gradients (Reisner et al. 2015). This study investigated gradients of combined grazing and moisture stresses, the latter of which was characterized by a combination of precipitation, soil texture, and landscape position. It remains unclear how facilitation between A. tridentata and perennial grasses responds over a broader geographical area and to a coarse measure of moisture (i.e., annual precipitation).

Our objective was to determine how associations between $A$. tridentata and 2 perennial grasses, Poa secunda (Sandberg bluegrass) and Elymus elymoides (bottlebrush squirreltail), varied under 2 grazing intensities (high and low) over a precipitation gradient in the Great Basin. We hypothesized that positive spatial associations indicative of shrub facilitation of grasses would be strongest in moderately stressful conditions: high grazing intensity/high precipitation and low grazing intensity/low precipitation (Fig. 1). We expected to observe net competitive interactions in 2 scenarios: (a) the least stressful conditions (low grazing intensity/high precipitation) because resources are less limiting and (b) the highest stress conditions (high grazing intensity/low precipitation) due to the breakdown of facilitation at extreme stress (Fig. 1; He and Bertness 2014). The disintegration of facilitative interactions may result from increased nurse plant-beneficiary competition at low moisture levels and/or a decrease in the protective benefit of shrub canopies at low moisture levels when vegetation production is limited and ungulates may forage more intensely under shrub canopies (Smit et al. 2009).

\section{Methods \\ Focal Species}

Artemisia tridentata ssp. wyomingensis is a long-lived perennial evergreen shrub that can live over 100 years (Welch 2005). It is relatively unpalatable to domestic cattle (Howard 1999) and has a rigid, closed canopy which is difficult for cattle to penetrate. The root system includes a long taproot and a shallow network of lateral roots (Welch 2005). Poa secunda (Sandberg bluegrass) and Elymus elymoides (bottlebrush squirreltail) are common native Great Basin perennial grasses that are palatable to domestic livestock (Brown and Amacher 1999, Booth et al. 2003). Poa secunda has a shallow fibrous root system and is tolerant of some drought due to its summer dormancy (Howard 1997). It is moderately grazing tolerant and is one of the first grasses to begin seasonal growth (Howard 1997). Elymus elymoides is short lived and roots at moderate depths. It is not as tolerant of drought as $P$. secunda (Humphrey and Schupp 2004) and is slightly more vulnerable to grazing, especially in the spring (Simonin 2001).

\section{Study Area and Site Selection}

The study area encompassed areas across Idaho and Nevada, USA, dominated by Wyoming big sagebrush (Fig. 2). We selected 5 paired high grazing/low grazing sites: 4 in the Central Owyhee High Plateau, and 1 in the Humboldt Area Major Land Resource Area (NRCS 2006). Mean annual precipitation at sites ranged from $220 \mathrm{~mm}$ to $340 \mathrm{~mm}$, which is typical annual precipitation for 


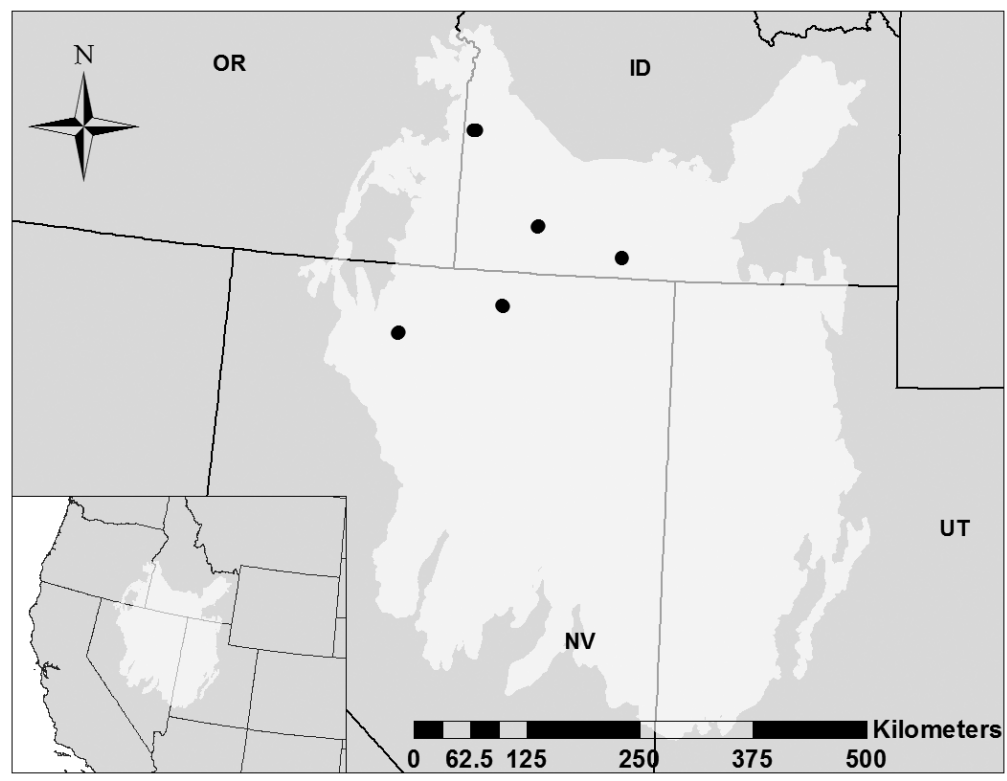

Fig. 2. Sampling sites in the northwest Great Basin (inset). Each dot represents a paired high-grazing and low-grazing site.

Wyoming big sagebrush ecological sites in the region. Mean annual precipitation was calculated over 1981-2010 using a ParameterElevation Regressions on Independent Slopes Model (PRISM), one of the most widely used and accurate weather models available (Daly and Bryant 2013). All sites were located on public land managed by the Bureau of Land Management (BLM).

Our initial 29 candidate sites were those sampled in a previous study investigating grass-shrub spatial associations over a precipitation gradient (Holthuijzen and Veblen 2015). The 29 sites were characterized by $<40 \%$ cheatgrass (Bromus tectorum) cover, presence of native deep- or short-rooted perennial grasses, and no recent history of burning or land treatments. All sites were described as having a shrub overstory of Artemisia tridentata spp. wyomingensis, a dominant herbaceous understory of bluebunch wheatgrass (Pseudoroegneria spicata) or Thurber's needlegrass (Achnatherum thurberianum), a subdominant herbaceous understory of Elymus elymoides and Poa secunda, and loamy soil according to the Natural Resources Conservation Service Ecological Site Description (ESD) system (https://esis.sc.egov.usda.gov/). Although sites were described in ESDs as being dominated by P. spicata or A. thurberianum in their reference state, we found that the major herbaceous species present at our sites were $P$. secunda and E. elymoides. Plant species nomenclature is based on the USDA PLANTS database (NRCS 2016).

From the pool of 29 sites, we selected 5 sites that fell across a precipitation gradient where we were able to determine locations of natural (streams, ponds) or artificial (troughs, artificial lakes) water sources known to have been utilized to some degree by livestock cattle for at least 5 years. At each site, we defined 2 plot types: low and high grazing intensity. Highintensity areas were located $200-400 \mathrm{~m}$ from a water source, and low-intensity plots were $\geq 800 \mathrm{~m}$ from a water source. Because grazing intensity attenuates with increasing distance from a water source, distance from water sources has been used to quantify long-term grazing intensity (Andrew 1988). We verified recent (short-term) high grazing intensity with observations of hoof prints, fresh dung, bite marks on grasses, and presence of nearby cattle (Table 1). Low grazing plots showed little to no signs of recent livestock activity.

\section{Sampling}

We investigated how spatial association between Wyoming big sagebrush (A. tridentata ssp. wyomingensis) and 2 common native 
TABLE 1 . Site attribute means (SE) and $t$ test results for high $(n=5)$ versus low $(n=5)$ grazing intensity sites.

\begin{tabular}{|c|c|c|c|c|}
\hline Variable & $\begin{array}{c}\text { High grazing } \\
\text { intensity }\end{array}$ & $\begin{array}{l}\text { Low grazing } \\
\text { intensity }\end{array}$ & $t$ & $P$ \\
\hline Gap size between perennial plants $(\mathrm{cm})$ & $275(168)$ & $110(22)$ & 0.99 & 0.38 \\
\hline Cattle dung patty density (patties $\cdot \mathrm{m}^{-2}$ ) & $0.14(0.03)$ & $0.05(0.03)$ & 2.15 & 0.10 \\
\hline A. tridentata density (plants $\cdot \mathrm{m}^{-2}$ ) & $1.2(0.3)$ & $0.94(0.2)$ & 0.94 & 0.40 \\
\hline Perennial grass density (plants $\cdot \mathrm{m}^{-2}$ ) & $0.35(0.10)$ & $0.88(0.30)$ & 2.13 & 0.10 \\
\hline Perennial grass $\%$ cover & $31.9(9.2)$ & $45.3(6.9)$ & 1.41 & 0.26 \\
\hline Annual grass \% cover & $9.0(6.4)$ & $8.7(4.1)$ & 0.05 & 0.96 \\
\hline Perennial forb $\%$ cover & $3.8(3.8)$ & $4.6(2.8)$ & 0.56 & 0.61 \\
\hline Annual forb \% cover & $8.9(4.6)$ & $3.5(2.0)$ & 0.92 & 0.41 \\
\hline Biological soil crust $\%$ cover & $1.2(1.0)$ & $3.5(2.8)$ & 1.23 & 0.29 \\
\hline Bare ground $\%$ cover & $16.4(4.7)$ & $15.3(5.5)$ & 0.34 & 0.75 \\
\hline
\end{tabular}

perennial grasses ( $P$. secunda and E. elymoides) responded to grazing intensity. In 2013, field sampling occurred between 15 May and 30 June to capture peak herbaceous biomass. At each of the 5 paired sites (10 total), we sampled 25-29 sagebrush individuals. We randomly selected focal shrubs by walking along three $50-\mathrm{m}$ lines that radiated, at equal spacing, from a single randomly selected point. At every $5 \mathrm{~m}$ we chose the nearest shrub, alternating between left and right sides of the transect. We targeted mature, vigorous individual plants by choosing sagebrush that met the following criteria: height $>40 \mathrm{~cm}$ (at the tallest part of live canopy), width $>40 \mathrm{~cm}$ (at both the longest axis of canopy and its perpendicular length), $>50 \%$ live canopy (visually estimated), and presence of a single distinguishable base stem. If a shrub did not fit our sampling criteria, we selected the next closest shrub until we found an appropriate shrub.

At each shrub (267 across all sites), we sampled transects extending from the shrub base in each of the 4 cardinal directions. At each transect, the "canopy" zone extended from shrub base to canopy dripline. When this distance was zero (in the case of asymmetric shrubs), we did not sample the canopy zone. The "interspace" zone varied among shrubs and extended from the canopy dripline to either (a) the midpoint between the canopy dripline and the nearest neighboring shrub canopy or (b) $200 \mathrm{~cm}$, if the nearest neighboring shrub canopy was more than $300 \mathrm{~cm}$ away. We used canopy intercept to record cover of E. elymoides along the entire length of these 4 transects. We also assessed E. elymoides density within a $40-\mathrm{cm}$ belt transect along each of the 4 transects. Due to the patchy growth form of $P$. secunda at our study sites, we made ocular estimates of its cover to the nearest $1 \%$ in $20 \times 20$-cm quadrats placed in the canopy (midpoint of canopy zone), at the edge (at canopy dripline, extending into interspace), and in the interspace (at both midpoint and end of the interspace) microsites.

Finally, to characterize overall site conditions, we measured the following attributes along all three 50-m transects at each of the 10 sites: gap size between perennial vegetation; densities of cattle dung, sagebrush, and cover of perennial bunchgrasses in 2-m-wide belt transects; and cover of perennial bunchgrasses, annual grasses, perennial forbs, annual forbs, biological soil crusts, and bare ground using the methods of Herrick et al. (2009).

\section{Analyses}

We used percent cover data for all $P$. secunda analyses and density data for all $E$. elymoides analyses. We were not able to use percent cover data for E. elymoides because there were too many zeros (primarily in highly grazed sites). Previous work shows that $E$. elymoides density and cover respond to precipitation in similar ways (Holthuijzen and Veblen 2015). For all analyses of $P$. secunda cover and E. elymoides density, we treated paired grazed/ungrazed sites as the replicated unit. Shrub-level data were incorporated into P. secunda models as subsamples of microsites within sites. For E. elymoides, however, the large number of zeros in the data prevented us from using individual shrub subsample values and instead required us to analyze pooled site-level means.

To characterize grass-shrub interactions, we first used the relative interaction index (RII), a widely used metric in ecology that characterizes the strength of plant-plant 
interactions (Armas et al. 2004). We calculated the RII for each grass species according to

$$
\text { RII }=\frac{\text { Canopy }_{\mathrm{C}}-\text { Interspace }_{\mathrm{C}}}{\text { Canopy }_{\mathrm{C}}+\text { Interspace }_{\mathrm{C}}},
$$

where $\left(\right.$ Canopy $\left._{C}\right)$ is percent cover or density in the canopy microsite of the target A. tridentata shrub and Interspace ${ }_{\mathrm{C}}$ is percent cover or density in the interspace adjacent to the shrub. RII values range from -1 (intense competition) to +1 (intense facilitation). For each grass species, we used a general linear mixed model to analyze how RII responded to 2 fixed factors: grazing intensity (high/low) and a continuous precipitation gradient $(220$ $\mathrm{mm}$ to $340 \mathrm{~mm}$ ). The model also included a precipitation*grazing intensity interaction, and total variance was partitioned into variance among site pairs.

To analyze absolute $P$. secunda cover and E. elymoides densities, we used 2 separate general linear mixed models. Each model included grazing intensity (high/low), microsite (canopy/interspace), and precipitation (continuous) as fixed effects. The $P$. secunda model also included precipitation $*$ grazing intensity and precipitation $*$ microsite interactions, while the E. elymoides model included only the grazing intensity* microsite interaction. Both models were first fit to include all possible 3-way interactions. In the final model for E. elymoides density, the 3-way interaction was removed to enhance explanatory power and avoid oversaturation of the model (the number of effects would have been too many for the sample size, $n=10$ ). For $P$. secunda, total variance was partitioned into variance among the 5 high/low-grazing site pairs, variance between high/low-grazing sites nested within a site pair, variance among microsites nested within a site, and residual variance (variance among subsamples). For E. elymoides, total variance was partitioned into variance among the 5 high/low-grazing site pairs, variance between high/low-grazing sites nested within a site pair, and residual variance (variance among microsites within a site). For $P$. secunda analyses, we used $t$ tests to make pairwise comparisons and to test if regression slope coefficients of the precipitation $*$ grazing and precipitation $*$ microsite interactions differed among sagebrush microsites and grazing intensity levels. We repeated this process for the grazing intensity* microsite interaction for E. elymoides. For both species, we standardized precipitation values around a mean of zero to avoid obtaining negative extrapolative cover values for lower precipitation; all typeIII tests of fixed effects are reported for standardized precipitation data. Percent cover values for $P$. secunda were arcsine square-root transformed, and density values for E. elymoides were square-root transformed prior to analysis to better meet assumptions of normality and homogeneity of variance.

To identify differences between high- and low-grazing sites with respect to site characteristics, we conducted paired $t$ tests for sitelevel means. Basal-gap size data were logtransformed to achieve residual normality and homogeneity of variances. All statistical analyses were conducted with SAS 9.3 (SAS 2010) using the PROC GLIMMIX procedure with the Kenward-Roger method for calculating degrees of freedom.

\section{Results}

\section{Precipitation-Driven Patterns}

The strength of facilitative interactions between $P$. secunda and A. tridentata decreased with increasing precipitation. Specifically, $P$. secunda showed stronger overall patterns of positive (i.e., facilitative) RII values at the lowest precipitation levels and a decrease to negative (competitive) values at the highest annual precipitation levels (effect of precipitation on RII: $F=14.95_{1,3.024}, P=0.03$; Fig. 3). The shift from positive RII values at low precipitation to negative RII values at high precipitation was driven by 2 factors: (1) greater absolute P. secunda cover in A. tridentata canopy versus interspace microsites at low precipitation levels (10th percentile of precipitation: canopy cover $=8.3 \%$; interspace cover $=2.6 \%$; Fig. 4 ) and (2) higher absolute $P$. secunda cover in interspace than in canopy microsites at high precipitation (90th percentile: canopy cover $=8.4 \%$; interspace cover $=12 \%$; precipitation $*$ microsite: $F_{1,3.014}=15.23, P=0.005$; Fig. 4).

The strength of facilitative interactions between E. elymoides and A. tridentata also tended to decrease with increasing precipitation (effect of precipitation on RII: $F_{1,3.014}=$ 13.43, $P=0.03$; Fig. 3). However, the relationships between E. elymoides and A. tridentata 


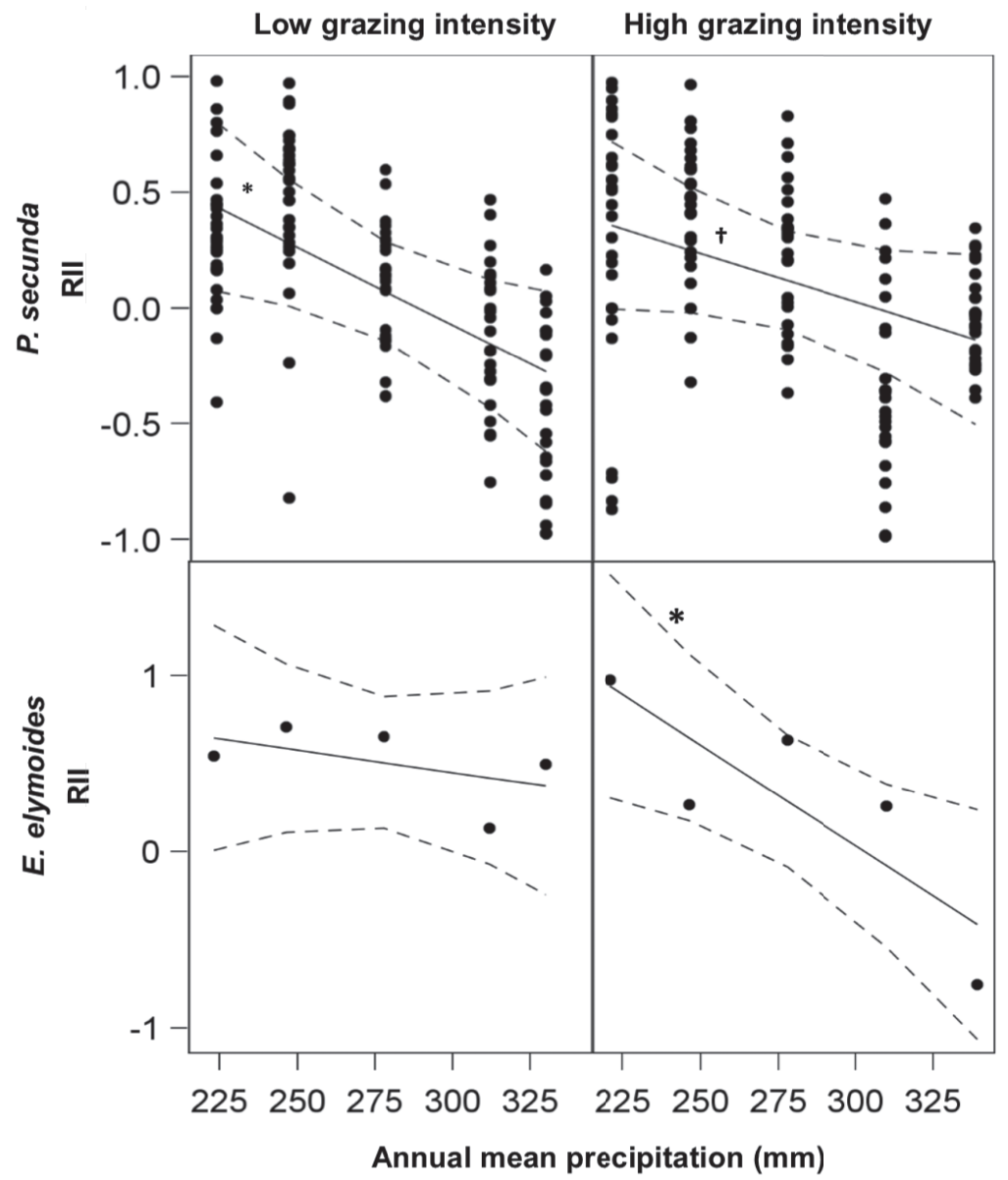

Fig. 3. Shrub-level means and predicted regression lines (with $95 \%$ confidence bands) for RII of Poa secunda and Elymus elymoides across precipitation level. Regression lines significantly different from zero at $P<0.05$ are denoted with an asterisk $(*)$, and those of marginal significance $(P<0.10)$ are denoted with a dagger $(\mathbf{t})$.

generally were positive, regardless of annual precipitation, with the exception of one site. For 9 out of 10 sites, RII was $>0$ (Fig. 3). The dominance of positive RII values for $E$. elymoides was due to the consistently greater absolute densities of E. elymoides in canopy versus interspace microsites (canopy density $=2.07$ plants $\cdot \mathrm{m}^{-2}$; interspace density $=0.67$ plants $\cdot \mathrm{m}^{-2}$; effect of sagebrush microsite $F_{2,18}=10.7, P=0.01$; Fig. 5).

\section{Interactions Between}

Precipitation and Grazing

For $P$. secunda, the pattern of facilitative interactions becoming increasingly competitive with increasingly wet conditions appeared to be strongest under lower grazing intensity.
The relationship (direction of slope) between absolute cover of $P$. secunda and precipitation differed according to grazing intensity and shrub microsite (Fig. 6). Specifically, under high grazing intensity, absolute cover of $P$. secunda increased in response to precipitation in both canopy and interspace microsites (marginally significantly and significantly, respectively; canopy microsites: slope $=0.03$, $\mathrm{t}_{9.082}=2.19, P=0.06$; interspace microsites: slope $=0.07, \mathrm{t}_{8.736}=5.81, P=0.0002$; Fig. 6 ). In contrast, under low grazing intensity, cover declined in response to increasing precipitation in canopy microsites (marginally significantly), but increased (nonsignificantly) with increasing precipitation in interspace microsites (canopy microsites: slope $=-0.02, \mathrm{t}_{8.736}=-2.03$, 
High grazing intensity

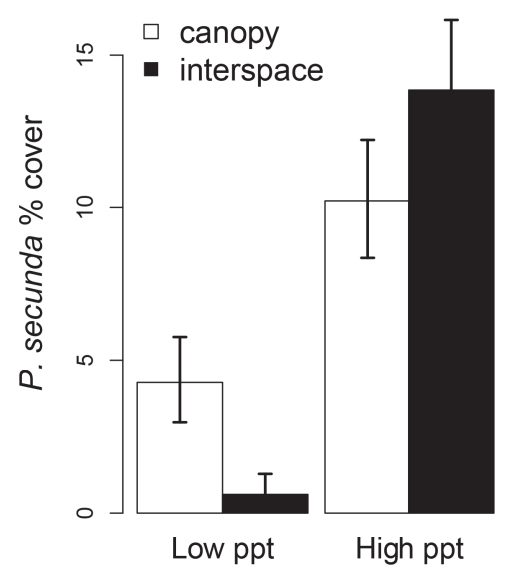

Low grazing intensity

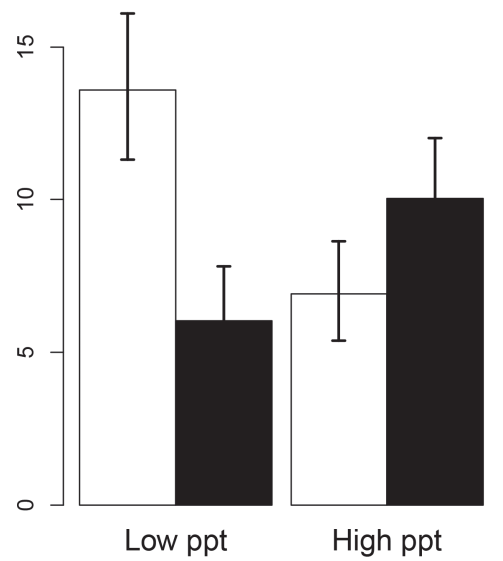

Fig. 4. Percent cover of Poa secunda in canopy and interspace microsites at low and high annual mean precipitation (10th and 90th percentiles) over high and low grazing intensities. Error bars represent one standard error. Percentages and standard errors were back-transformed from the arcsin square-root scale.

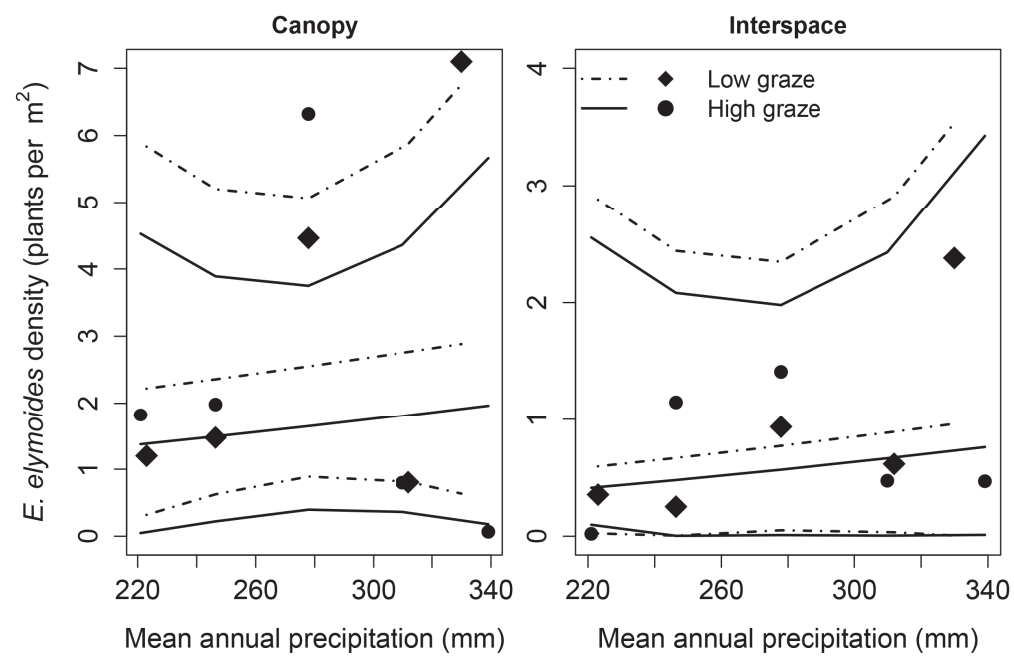

Fig. 5. Back-transformed means and predicted regression lines (with $95 \%$ confidence bands) for absolute densities of Elymus elymoides at 10 sites across a precipitation gradient, in canopy and interspace microsites, and at high and low grazing intensity. No slopes were significantly different from zero.

$P=0.07$; interspace microsites: slope $=0.02$, $\mathrm{t}_{8.736}=1.4, P=0.20$; Fig. 6). Moreover, under low precipitation, grazing made it less beneficial to grow under canopies of A. tridentata: under low precipitation, the magnitude of the difference between canopy and interspace cover was smaller under high grazing intensity (difference of $\sim 3.7 \%$ cover; Fig. 4) than low grazing intensity (difference of $\sim 7.6 \%$ cover, Fig. 4 ).
These patterns in absolute cover were not strong enough to result in a significant precipitation * grazing effect on RII $\left(F_{1,2.95}=0.86\right.$, $P=0.42$ ). However, examination of the slopes of RII provide some support for stronger precipitation-driven facilitation under lower grazing (Fig. 3). Under low grazing intensity, $P$. secunda RII decreased significantly from facilitative $(+0.7)$ at low precipitation to competitive $(-0.25)$ at high precipitation 


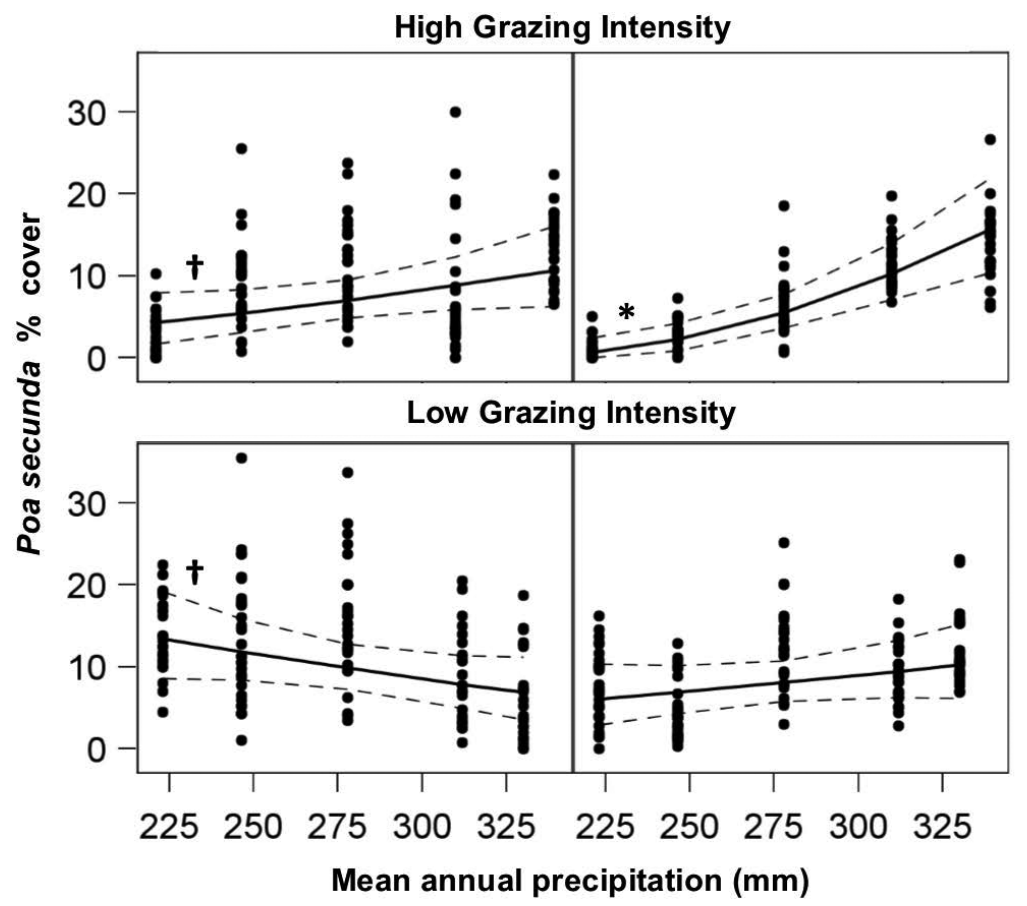

Fig. 6. Back-transformed shrub-level means and predicted regression lines (with $95 \%$ confidence bands) for percent cover of Poa secunda across a precipitation gradient for canopy and interspace microsites at high and low grazing intensities. Regression lines significantly different from zero at the $P<0.05$ level are denoted with and an asterisk $(*)$, and those of marginal significance $(P<0.10)$ are denoted with a dagger $(\mathbf{t})$.

(slope $=-0.17, t_{3.35}=-3.77, P=0.02 ;$ Fig. 3 ). For $P$. secunda, the trend of increasingly competitive interactions with increasing precipitation was also present at high grazing intensity; however, the magnitude of the difference in RII between high and low precipitation was smaller $(+0.3$ at low precipitation to -0.1 at high precipitation), and the slope was only marginally significant (slope $=-0.11$, $t_{3.297}=-2.52, P=0.08$; Fig. 3).

Neither grazing nor its interaction with precipitation significantly affected the relationship of E. elymoides with A. tridentata. The effect of grazing on RII for E. elymoides was not significant $\left(F_{1,3}=0.82, P=0.43\right)$; neither was the interaction of grazing * precipitation $\left(F_{1,3.024}=2.17, P=0.24\right)$.

\section{Site Characteristics}

Site characteristics did not differ statistically between high and low grazing intensity sites (Table 1). However, high grazing intensity sites showed nonsignificant trends $(P=0.10)$ toward higher cattle dung densities and lower perennial grass densities.

\section{Discussion}

Relatively little is known about how biotic and abiotic stresses interact to influence plant-plant relationships and, in particular, whether facilitative relationships will break down under the most stressful conditions. We found that the native perennial grasses $P$. secunda and E. elymoides both were positively associated with A. tridentata canopy microsites in stressful conditions, at the lowest annual precipitation levels. For $P$. secunda, the addition of biotic (grazing) stress appeared to weaken this effect, indicating a potential breakdown in facilitation in highly stressful conditions (e.g., low moisture conditions and high grazing stress), as we had predicted. Our results did not entirely support our prediction that facilitation would dominate in the 2 scenarios we considered to be moderately stressful. For both grass species, facilitation dominated in one scenario (low grazing/low precipitation) but did not in the second (high grazing/ high precipitation). 


\section{Facilitation and Moisture Stress}

The effects of abiotic (moisture) stress on plant spatial patterns were consistent with the stress gradient hypothesis in 2 significant ways. First, we found that both $P$. secunda and E. elymoides were positively associated with A. tridentata canopy microsites at low annual precipitation levels. Second, for P. secunda, the strength of facilitation decreased with increasing annual precipitation. Interactions between $A$. tridentata and $P$. secunda generally shifted from facilitative to net competitive as annual precipitation increased, which is consistent with the results of other Great Basin studies (Davies et al. 2007, Holthuijzen and Veblen 2015, Reisner et al. 2015).

Interactions between E. elymoides and A. tridentata, on the other hand, deviated from this pattern: interactions were indicative of net facilitation at most sites, regardless of precipitation. The facilitative effects we observed were mainly due to greater densities of $E$. elymoides in sagebrush canopy than interspace microsites. These results are consistent with Reisner (2010), Davies et al. (2007), and Holthuijzen and Veblen (2015) who also found evidence that $E$. elymoides cover and density are facilitated by $A$. tridentata in most areas of the Great Basin. In general, E. elymoides may benefit to a greater extent from improved soil moisture conditions in sagebrush canopies compared to $P$. secunda because it is less drought tolerant.

\section{Grazing Effects}

We found that grazing generally weakens precipitation-driven grass-shrub relationships. In particular, facilitative interactions between $P$. secunda and $A$. tridentata were not as strong when moisture was limiting and grazing intensity was high. Specifically, under dry conditions, the magnitude of the benefit of growing in canopy microsites (relative to interspaces) was less under high than low grazing. We suggest that canopy microsites offer less protection to $P$. secunda from grazing animals in dry conditions due to covariance of moisture and grazing stresses; in particular, in semiarid systems, grazing can be more intense under low precipitation (Knapp 1996, Veblen 2008). Accordingly, we found that, at low annual precipitation, high grazing intensity resulted in a considerable reduction of $P$. secunda cover (relative to low grazing intensity) in canopy microsites. This reduction in cover could be attributed to an increase in the search intensity of grazing animals when low moisture limits overall vegetation production and forage resources (Soliveres et al. 2011). In this scenario, A. tridentata may be less effective in shielding subcanopy $P$. secunda plants from grazing.

This type of reduction in associational resistance has been documented at extreme levels of consumer pressure (Smit et al. 2007). Verwijmeren et al. (2014) found that as grazing pressure increased on (drier) south-facing slopes in southeastern Spain, plant-plant facilitation was reduced. In contrast, herbivory has been shown to intensify abiotically driven facilitation elsewhere (Graff et al. 2007, Veblen 2008). Previous work in the Great Basin by Reisner et al. (2015) found strong facilitative interactions between $P$. secunda and A. tridentata at the highest levels of combined moisture and grazing stresses, seemingly in contrast to our results. However, their study used both a gradient of grazing intensity (as opposed to 2 levels in our study) and a more precise approach to characterizing moisture based on precipitation, soil texture, and landscape position. These factors combined with the smaller geographic scope of their study may mean that maximum stress levels in their study were lower than ours. Nonetheless, despite a small sample size, our study suggests that, based on a very coarse predictor of moisture stress (mean annual precipitation), facilitative processes may break down at the highest stress levels. Although we used distance from water to distinguish our 2 (longterm) grazing treatments, differences in cow pies and perennial grass cover (2 indicators of recent grazing intensity) between grazed and ungrazed areas were only marginally significant; greater sampling effort and reexamination of these patterns would help determine whether the grazing effects we observed were genuine.

We also found that grazing may have reduced the magnitude of the net competitive interactions we observed at high annual precipitation for $P$. secunda. At high precipitation, RII was slightly less negative (i.e., more weakly competitive) under high than low grazing intensity, suggesting that grazing stress either reduced competition between $P$. secunda and $A$. tridentata or increased any facilitative interactions between the 2 plants. These 
results are consistent with Verwijmeren et al. (2014), who also found that, in wetter conditions, net competitive interactions between 2 plant species were reduced as grazing pressure and the effect of associational resistance increased.

\section{Intermediate Stress Levels}

We expected facilitative effects to be greatest under our 2 intermediate stress level scenarios: low grazing/low precipitation and high grazing/high precipitation. Consistent with our expectation, we did observe net facilitative effects of $A$. tridentata on $P$. secunda under one set of intermediate stress conditions (low grazing/low precipitation). However, $P$. secunda also deviated from this expectation and showed net competitive responses under the other set of intermediate stress conditions (high grazing/high precipitation). These results were surprising because grazing often drives net facilitation when thorny or otherwise unpalatable neighbors protect vulnerable understory plants (e.g., Graff and Aguiar 2011). However, there is some evidence that grazing-mediated facilitation only occurs in drier conditions (Veblen 2008). At high precipitation levels where moisture should be more readily available in both canopy and interspace microsites, grazing-tolerant species such as $P$. secunda may benefit more from growing in interspaces to avoid competition with nurse shrubs (i.e., the benefit of lower competition in interspaces may outweigh any protection from grazing offered by shrub canopies).

Elymus elymoides also appeared to respond contrary to our prediction, showing a net competitive response under high precipitation/high grazing conditions. This was surprising because a previous study, Holthuijzen and Veblen (2015), found that a smaller proportion of $E$. elymoides plants were grazed in canopy versus interspace microsites; so we would have expected $E$. elymoides to benefit more from physical protection from grazing. However, our current results were driven by patterns at a single site which was grazed more heavily than all other sites, as evidenced by low grass cover in both canopy and interspace microsites (despite the high precipitation and expectation of higher productivity and cover at the site; MFH, personal observation). Suffi- ciently heavy grazing at this site could have caused animals to preferentially select more nutritious under-canopy plants (sensu Smit et al. 2007). Because our regressions were each based on only 5 points, a greater sampling effort would help determine whether the shift from facilitative to competitive is genuine or an artifact of small sample size.

\section{Implications}

We found that naturally occurring $P$. secunda and E. elymoides plants were associated with $A$. tridentata canopy microsites, particularly in drier areas. Grazing also appeared to weaken facilitation when precipitation was limiting but may also have weakened competition when precipitation was high. Under moderately stressful conditions, facilitation did not always dominate. Rather, in the moderate conditions of high grazing under high precipitation, the benefits of increased precipitation appeared to outweigh any negative effects of grazing.

Our results may assist land managers in anticipating how Great Basin plant communities may respond to the separate and combined effects of grazing and climate change. Although predictions for precipitation in this region are variable and uncertain, it is likely that summer precipitation will decrease and droughts will increase in frequency and intensity; it is also clear that temperatures will continue to warm (Polley et al. 2013, Melillo et al. 2014). Together, these conditions are likely to increase moisture stress for plants. Our results suggest that such increases in moisture stress may increase the frequency or importance of facilitative grassshrub interactions, and perennial grasses may preferentially grow under sagebrush canopies. Our results further suggest that higher levels of grazing may moderate this effect, though not by encouraging more plant growth in interspaces but by reducing absolute grass cover, regardless of microsite. This pattern may be especially true if stocking densities are not reduced in drier areas where forage quality and quantity are expected to decrease with climate change (Polley et al. 2013). In such cases, reduced perennial grass cover could leave both interspace and subcanopy microsites even more vulnerable to invasion by undesirable annual grasses such as Bromus tectorum. 


\section{ACKNOWLEDGMENTS}

We thank the National Science Foundation (GRFP to MFH), Utah State University Ecology Center, Utah Agricultural Experiment Station, and The Great Basin Native Plant Project for funding. Many thanks to Susan Durham for statistical assistance and to Karin Kettenring, Tom Monaco, and Peter Adler for reading previous versions of the manuscript. Brittany Duncan, Konnon Smith, and Megan Dettenmaeier provided field assistance. This research was approved as Utah Agricultural Experiment Station journal paper \#8819.

\section{Literature Cited}

ANDREW, M. 1988. Grazing impact in relation to livestock watering points. Trends in Ecology and Evolution 3:336-339

Anthelme, F., L. Gómez Aparicio, and R. Montúfar. 2014. Nurse-based restoration of degraded tropical forests with tussock grasses: experimental support from the Andean cloud forest. Journal of Applied Ecology 51:1534-1543.

Armas, C., R. Ordiales, and F.I. Pugnaire. 2004. Measuring plant interactions: a new comparative index. Ecology 85:2682-2686.

Atsatt, P.R., And D.J. O’Dowd. 1976. Plant defense guilds. Science 193:24-29.

Bertness, M.D., and R. Callaway. 1994. Positive interactions in communities. Trends in Ecology and Evolution 9:191-193.

Booth, M.S., M.M. Caldwell, and J.M. Stark. 2003. Overlapping resource use in three Great Basin species: implications for community invasibility and vegetation dynamics. Journal of Ecology 91:36-48.

Brooker, R.W., F.T. Maestre, R.M. Callaway, C.L. Lortie, L.A. Cavieres, G. Kunstler, P. Liancourt, K. Tielbörger, J.M. Travis, and F. Anthelme. 2008. Facilitation in plant communities: the past, the present, and the future. Journal of Ecology 96:18-34.

Brown, R.W., AND M.C. Amacher. 1999. Selecting plant species for ecological restoration: a perspective for land managers. Pages 1-16 in L.K. Holzworth and R.W. Brown, editors, Revegetation with native species: Proceedings, 1997 Society for Ecological Restoration annual meeting; 1997 November 12-15; Fort Lauderdale, FL. Proc. RMRS-P-8, U.S. Department of Agriculture, Forest Service, Rocky Mountain Research Station, Ogden, UT.

Callaway, R.M., E.H. Delucia, D. Moore, R. Nowak, AND W.H. SCHLESINGER. 1996. Competition and facilitation: contrasting effects of Artemisia tridentata on desert vs. montane pines. Ecology 77:2130-2141.

Callaway, R.M., D. Kikodze, M. Chiboshvili, and L. Khetsuriani. 2005. Unpalatable plants protect neighbors from grazing and increase plant community diversity. Ecology 86:1856-1862.

Cardon, Z.G., J.M. Stark, P.M. Herron, and J.A. RasMUSSEN. 2013. Sagebrush carrying out hydraulic lift enhances surface soil nitrogen cycling and nitrogen uptake into inflorescences. Proceedings of the National Academy of Sciences 110:18988-18993.
Chambers, J.C. 2001. Pinus monophylla establishment in an expanding Pinus-Juniperus woodland: environmental conditions, facilitation and interacting factors. Journal of Vegetation Science 12:27-40.

Daly, C., And K. BRyant. 2013. The PRISM climate and weather system-an introduction. PRISM climate group, Corvallis, OR.

Davies, K.W., J.D. Bates, and R.F. Miller. 2007. The influence of Artemisia tridentata ssp. wyomingensis on microsite and herbaceous vegetation heterogeneity. Journal of Arid Environments 69:441-457.

Davies, K.W., C.S. Boyd, J.L. Beck, J.D. Bates, T.J. SveJCAR, AND M.A. GREGG. 2011. Saving the sagebrush sea: an ecosystem conservation plan for big sagebrush plant communities. Biological Conservation $144: 2573-2584$

Graff, P., And M.R. Aguiar. 2011. Testing the role of biotic stress in the stress gradient hypothesis. Processes and patterns in arid rangelands. Oikos 120:1023-1030.

Graff, P., M.R. Aguiar, and E.J. Chaneton. 2007. Shifts in positive and negative plant interactions along a grazing intensity gradient. Ecology 88:188-199.

He, Q., and M.D. Bertness. 2014. Extreme stresses, niches, and positive species interactions along stress gradients. Ecology 95:1437-1443.

He, Q., M.D. Bertness, AND A.H. Altieri. 2013. Global shifts towards positive species interactions with increasing environmental stress. Ecology Letters 16:695-706.

Herrick, J.E., J.W. van Zee, K.M. Havstad, L.M. Burkett, AND W.G. Whitford. 2009. Monitoring manual for grassland, shrubland and savanna ecosystems, Volume I. Jornada Experimental Range, Las Cruces, NM.

Holmgren, M., M. Scheffer, and M.A. Huston. 1997. The interplay of facilitation and competition in plant communities. Ecology 78:1966-1975.

Holthuijzen, M.F., and K.E. Veblen. 2015. Grass-shrub associations over a precipitation gradient and their implications for restoration in the Great Basin, USA. PLOS ONE 10(12):e0143170.

HowarD, J.L. 1997. Poa secunda. In: Fire Effects Information System [online]. U.S. Department of Agriculture, Forest Service, Rocky Mountain Research Station, Fire Sciences Laboratory (Producer); [accessed 8 June 2016]. http://www.fs.fed.us/database/feis

HowARD, J.L. 1999. Artemisia tridentata subsp. wyomingensis. In: Fire Effects Information System [online]. U.S. Department of Agriculture, Forest Service, Rocky Mountain Research Station, Fire Sciences Laboratory; [accessed 8 June 2016]. http://www.fs .fed.us/database/feis/plants/shrub/arttriw/all.html

Howard, K.S.C., D.J. EldRidge, AND S. Soliveres. 2012. Positive effects of shrubs on plant species diversity do not change along a gradient in grazing pressure in an arid shrubland. Basic and Applied Ecology 13:159-168.

Humphrey, L.D., AND E.W. SChupp. 2004. Competition as a barrier to establishment of a native perennial grass (Elymus elymoides) in alien annual grass (Bromus tectorum) communities. Journal of Arid Environments 58:405-422.

Knapp, P.A. 1996. Cheatgrass (Bromus tectorum L) dominance in the Great Basin Desert-History, persistence, and influences to human activities. Global Environmental Change 6:37-52.

Le Bagousse-Pinguet, Y., E.M. Gross, and D. Straile. 2012. Release from competition and protection 
determine the outcome of plant interactions along a grazing gradient. Oikos 121:95-101.

Liu, N., H. Ren, S. Yuan, Q. Guo, and L. Yang. 2013. Testing the stress gradient hypothesis during the restoration of tropical degraded land using the shrub Rhodomyrtus tomentosa as a nurse plant. Restoration Ecology 21:578-584.

Maestre, F.T., S. Bautista, J. Cortina, and J. Bellot. 2001. Potential for using facilitation by grasses to establish shrubs on a semiarid degraded steppe. Ecological Applications 11:1641-1655.

Maestre, F.T., F. Valladares, and J.F. Reynolds. 2005. Is the change of plant-plant interactions with abiotic stress predictable? A meta analysis of field results in arid environments. Journal of Ecology 93:748-757.

Melillo, J.M., T.C. Richmond, And G.W. Yohe, EDitors. 2014. Climate change impacts in the United States: the third national climate assessment. U.S. Global Change Research Program. 841 pp. http://dx.doi.org/ 10.7930/J0Z31WJ2.

Moro, M.F., F. Pugnaire, P. Haase, and J. PuigdefábreGAS. 1997. Effect of the canopy of Retama sphaerocarpa on its understorey in a semiarid environment. Functional Ecology 11:425-431.

Noumi, Z., M. Chaieb, R. Michalet, and B. Touzard. 2015. Limitations to the use of facilitation as a restoration tool in arid grazed savanna: a case study. Applied Vegetation Science 18:391-401.

[NRCS] Natural Resources Conservation Service. 2006. Land resource regions and major land resource areas of the United States, the Caribbean, and the Pacific Basin. U.S. Department of Agriculture, Natural Resources Conservation Service Handbook 296.

[NRCS] Natural Resources Conservation Serivce. 2016. The PLANTS Database. National Plant Data Team, Greensboro, NC; [accessed 8 June 2016]. http:// plants.usda.gov.

Pazos, G., A. Bisigato, and M. Bertiller. 2007. Abundance and spatial patterning of coexisting perennial grasses in grazed shrublands of the Patagonian Monte. Journal of Arid Environments 70:316-328.

Perea, R., AND L. GiL. 2014. Shrubs facilitating seedling performance in ungulate-dominated systems: biotic versus abiotic mechanisms of plant facilitation. European Journal of Forest Research 133:525-534.

Polley, H.W., D.D. Briske, J.A. Morgan, K. Wolter, D.W. BAILEY, AND J.R. BROWN. 2013. Climate change and North American rangelands: trends, projections, and implications. Rangeland Ecology and Management 66:493-511.

Puigdefábregas, J. 1998. Ecological impacts of global change on drylands and their implications for desertification. Land Degradation and Development 9:393-406.

Ramírez, L.A., F. RaDA, and L.D. Llambí. 2015. Linking patterns and processes through ecosystem engineering: effects of shrubs on microhabitat and water status of associated plants in the high tropical Andes. Plant Ecology 216:213-225.

Rebollo, S., D.G. Milchunas, I. NoY-Meir, and P.L. ChapMAN. 2002. The role of a spiny plant refuge in structuring grazed shortgrass steppe plant communities. Oikos 98:53-64.

ReisNer, M.D. 2010. Drivers of plant community dynamics in sagebrush steppe ecosystems: cattle grazing, heat and water stress. Doctoral dissertation, Oregon State University, Corvallis, OR.

Reisner, M.D., P.S. Doescher, and D.A. Pyke. 2015. Stress-gradient hypothesis explains susceptibility to Bromus tectorum invasion and community stability in North America's semi-arid Artemisia tridentata wyomingensis ecosystems. Journal of Vegetation Science 26:1212-1224.

Richards, J.H., and M.M. Caldwell. 1987. Hydraulic lift: substantial nocturnal water transport between soil layers by Artemisia tridentata roots. Oecologia 73:486-489.

Saiz, H., and C.L. Alados. 2012. Changes in semi-arid plant species associations along a livestock grazing gradient. PLOS ONE 7(7):e40551.

SAS. 2010. SAS Version 9.3, Statistical Analysis Software. SAS Institute, Inc., Cary, NC.

Simonin, K.A. 2001. Elymus elymoides. In: Fire Effects Information System [online]. U.S. Department of Agriculture, Forest Service, Rocky Mountain Research Station, Fire Sciences Laboratory; [accessed 8 June 2016]. http://www.fs.fed.us/database/feis

SMit, C., M. RietKerk, AND M.J. Wassen. 2009. Inclusion of biotic stress (consumer pressure) alters predictions from the stress gradient hypothesis. Journal of Ecology 97:1215-1219.

Smit, C., C. Vandenberghe, J. Den Ouden, and H. MüLLER-SCHÄRER. 2007. Nurse plants, tree saplings and grazing pressure: changes in facilitation along a biotic environmental gradient. Oecologia 152: $265-273$.

Soliveres, S., P. García Palacios, A.P. Castillo Monroy, F.T. Maestre, A. Escudero, and F. ValLADARES. 2011. Temporal dynamics of herbivory and water availability interactively modulate the outcome of a grass-shrub interaction in a semi-arid ecosystem. Oikos 120:710-719.

Tielbörger, K., AND R. KADMON. 2000. Temporal environmental variation tips the balance between facilitation and interference in desert plants. Ecology 81:1544-1553.

Valiente-Banuet, A., And E. Ezcurra. 1991. Shade as a cause of the association between the cactus Neobuxbaumia tetetzo and the nurse plant Mimosa luisana in the Tehuacan Valley, Mexico. Journal of Ecology 79:961-971.

Veblen, K.E. 2008. Season- and herbivore-dependent competition and facilitation in a semiarid savanna. Ecology 89:1532-1540.

Verwijmeren, M., M. Rietkerk, S. Bautista, A.G. Mayor, M.J. Wassen, and C. Smit. 2014. Drought and grazing combined: contrasting shifts in plant interactions at species pair and community level. Journal of Arid Environments 111:53-60.

WELCH, B.L. 2005. Big sagebrush: a sea fragmented into lakes, ponds, and puddles. General Technical Report RMRS-GTR-144, U.S. Department of Agriculture, Forest Service, Rocky Mountain Research Station, Fort Collins, CO. 210 pp.

Ziffer-Berger, J., P.J. Weisberg, M.E. Cablk, and Y. OsEM. 2014. Spatial patterns provide support for the stress-gradient hypothesis over a range-wide aridity gradient. Journal of Arid Environments 102:27-33.

Received 21 December 2015 Accepted 9 June 2016 